\title{
Comparative Study of Duress in Certain Religious Penalties in Imami Jurisprudence and Islamic Penal Code
}

\author{
Kamalipour Ravari Elahe ${ }^{1} \&$ Taram Meysam ${ }^{2}$ \\ ${ }^{1}$ Kerman Shahid Bahonar University, Iran \\ ${ }^{2}$ Department of Theology, Kerman Shahid Bahonar University, Iran \\ Correspondence: Kamalipour Ravari Elahe, M.A in field of criminal law and Criminology, Kerman Shahid \\ Bahonar University, Iran.
}

Received: April 27, $2016 \quad$ Accepted: May 23, $2016 \quad$ Online Published: June 29, 2016
doi:10.5539/jpl.v9n5p88
URL: http://dx.doi.org/10.5539/jpl.v9n5p88

The paper derived from thesis under the title of comparative study of duress in Imami Jurisprudence and Islamic Penal Code.

\begin{abstract}
According to freedom of will, people are responsible for what they do and due to this principle, they would be punished. However, whenever human's will is distorted for some reason, punishment would be null and void. One of these reasons that can distort individual will is the principle of duress that is discussed in Imami Jurisprudence and Islamic Penal Code several times. Hence, almost in all crimes that their penalties are codified in Islamic Penal Code, duress can cause disclaimer of the coercer; unless about duress in murder. Although there are many disputes among jurists on retaliation or lack of retaliation for this crime, opinion of majority of jurists on acceptance of retaliation is accepted by the legislator. About other crimes like duress in adultery and sodomy, the coercer would be disclaimed; unless in cases that the criminal claims for coercion. In this case, legislator accepts principle of lack of duress and makes the court responsible for investigations. However, in Imami jurisprudence, the sentence would be issued for disclaimer of the coercer immediately after creation of doubt for judge and in case of probability of accuracy of claim.
\end{abstract}

Keywords: comparative study, Imami jurisprudence, duress, Islamic Penal Code, Criminal responsibility

\section{Introduction}

Because of association of free will and intent of criminal in intentional violation of values and social criminal norms, mental element brings criminal responsibility against criminal person and usefulness of punishment for the society. The element is considered under titles like satisfaction and intention in field of general conditions of liability not only in Common Law, but also in Islamic Penal Jurisprudence. Today, criminal laws across the world have emphasis on necessity of existence of two elements of will and intention to commit crime.

The principles of necessity of mental element have made any kind of reason to distort it to avoid committing crime and criminal responsibility. This issue has been constantly considered by different legislators around the world, since lack of existence or apparent or unrealistic achievement of this element can prevent possibility to prove crime spiritually and punishment of the criminal person.

Duress, in which criminal will is not considered, can be considered among affairs that cause damage for mental element of crime. Hence, if a criminal action is taken as a result of duress because of lack of will, it should not result in punishment. Discriminating the concept of duress and determining its meanings can clear position of this factor that can disclaim criminal liability in jurisprudence and Islamic Penal Code, its function and manner of disclaimer against crime.

Duress lexically means dislike, unwillingness and to force someone to do something (Moien, 1992, vol.3, 330).

In juridical books, it means forcing someone to create something that has duress to create it through frightening the person from leaving that action through threatening to hurt him/her in terms of life or property (Isfahani, 1973, vol.2, 281). 


\section{Duress in Certain Religious Penalties}

Shiite jurisprudence, despite to statutes of other countries, has not codified penal discussions on basis of crimes, but also it has accepted the principles of legality of crime and punishment and has codified the discussions on basis of penalties. The great scholars of Islam have divided great Islamic interests to 5 groups as follows: Keep the soul, keep the faith, keep the wisdom, keep self and keep wealth. Violation of each interest can be also a crime. As a result, crimes in Islam can be divided to 5 groups. First, crimes created by violation of soul like murder and mutilation; second, crimes created by violation of religion and faith like apostasy; third, crimes created by violation of generation like adultery and sodomy; fourth, crimes created by violation of wisdom like drinking alcohol and fifth, crimes created by violation of wealth and property like theft.

If the 5 groups are replaced in a pyramid, crimes in terms of heaviness can be divided to three groups as follows:

First, crimes causing Hadd: crimes that their punishment is Hadd and is specified in Holy Religion

Second, crimes causing nemesis (Qisas): crimes that their punishment is soul nemesis or organ nemesis (Qisas)

Third, crimes causing Ta'zir (chastising): crimes that their punishment is specified by holy legislator

Among the mentioned punishments, Hudud and Qisas are penalties that have been specified in holly religion (Shari'a) and hence, it has been tried to investigate the disclaimer against crime in these cases.

\section{Duress in Crimes Resulting in Hadd}

Article 15 of Islamic Penal Code (approval of 2013) has defined Hadd as follows: "Hadd is a punishment for which the grounds for, type, amount and conditions of execution are specified in holy Shari'a". As a result, if someone commits such crime intentionally, determined Hadd would be executed for him/her, since people are responsible for what they do and would be punished based on principle of freedom of will. However, Islamic Sharia that is created based on taking easy in all fields, especially, avoids execution of Hadd and punishment and takes disclaimer against crime of coercer in case of existence of coercion.

\section{Duress in Adultery}

In juridical terms, adultery (Zina) means illegal sexual intercourse of man and woman that is one of the big sins in Islam. In this field, Holly God has mentioned in verse 2 of Surah Nur that: " The [unmarried] woman or [unmarried] man found guilty of sexual intercourse - lash each one of them with a hundred lashes, and do not be taken by pity for them in the religion of Allah, if you should believe in Allah and the Last Day. And let a group of the believers witness their punishment."

The drafters of Islamic Penal Code (2013) have used legal basis and defined Zina in article 221 as follows: "Zina is defined as sexual intercourse of a man and a woman who are not married to each other, and also provided that the intercourse is not done by mistake."

Proving criminal responsibility in every crime like Zina is depended on conditions including maturity, wisdom and will that are called as general conditions of responsibility. On this basis, about Zina, human responsibility that is basis for criminal responsibility of doer of Zina would be analyzed in this manner that maturated people can use their will and resist against their sexual instincts and satisfy their sexual intentions in framework of legal and common regulations of their society; otherwise, if an action is taken by responsible person to satisfy sexual instincts out of common regulations of the society, the action can result in responsibility of the (Zani) Adulterer and the (Zanie) adulteress; unless the adulterer is forced to do that. If so, criminal responsibility of Zani or zanieh would be resolved. In this field, Surah Nur verse 33 has mentioned that: "And force not your maids to prostitution when they desire to live in chastity in order that you may get some goods of this world's life. And whosoever will force them then undoubtedly, Allah after this that they remain in compulsion is Forgiving, Merciful."

One of the disputes among jurists is acceptance or lack of acceptance of duress by adulterer. In this regard, majority of jurists believe that duress can meet responsibility of both Adulterer and Adulteress and mention their reason as follows: both man and woman are common in concept of coercion that can result in collapse of punishment sentence and lack of achievement of coercion in right of man needs being responsible for something that is out of ability of man (Shahid Sani, 2012, 650).

On the contrary, another group believes that duress on adultery is not realized for man, since lust is not an intentional action that is in limit of ability of man and fear of God can prevent erection (ibid).

Majority of jurists have rejected the statement and have considered achievement of adultery depending on realization of ablution to answer the problem, since ablution would be required entry of penis (Khomeini, 1990, 
vol.4, 174).

Legislator of Islamic Penal Code (approval of 1991) has accepted duress on behalf of man and woman clearly and has mentioned in article 67 as follows: " If either the adulterer or the adulteress claims to have been under duress while committing the act of adultery, he or she shall not be punished if his or her claim is not otherwise clearly disproved." Moreover, article 82 (paragraph 1) has emphasized acceptance of idea of majority of jurists and has mentioned that: " The penalty for adultery in the following cases shall be death, regardless of the age or marital status of the culprit: (1) Adultery with one's consanguineous relatives (close blood relatives forbidden to each other by religious law); (2) Adultery with one's stepmother in which the adulterer's punishment shall be death; (3) Adultery between a non-Muslim man and a Muslim woman, in which case the adulterer (non-Muslim man) shall receive the death penalty; (4) Forcible rape, in which case the rapist shall receive the death penalty." Legislator has added the adjective of coercer to adulterer to permit intention of entrance of both genders; although legislator of Islamic Penal Code (2013) has considered words duress and violation as synonyms; although they are different in terms of word and concept. Through deleting the title "coercer" after adulterer, the legislator believes that formation of duress in adultery can be created just by adulterer man and not adulteress woman. Article 224 has mentioned in this field that: " In the following cases the hadd punishment for zina is the death penalty:

(a) Zina with blood relatives who are prohibited to marry.

(b) Zina with a step-mother; in which case, the man who committed zina shall be sentenced to the death penalty.

(c) Zina of a non-Muslim man with a Muslim woman; in which case, the man who committed zina shall be sentenced to the death penalty.

(d) Zina committed by duress or force [i.e. rape]; in which case, the man who committed zina by duress or force shall be sentenced to the death penalty.

Note 1- Punishment of the woman who has committed zina in paragraphs (b) and (c) shall be in accordance with other provisions of zina.

Note 2- The conduct of anyone who commits zina with a woman who did not consent to engage in zina with him, while she is unconscious, asleep, or drunk, shall be regarded as zina committed by coercion [i.e. rape]. In cases of zina by deceiving and enticing a non-pubescent girl, or by abducting, threatening, or intimidating a woman, even if she surrenders herself as a result of that, the abovementioned rule shall apply." Accordingly, it seems that despite to acceptance of duress by adulterer among majority of Imami jurists, Islamic Penal Code legislator (2013) have not accepted this issue through a strict view. In fact, firstly if man is forced to do something in case of realization of this issue that is out of his authority, secondly, if duress is unbearable, accepting punishment for man is against principles of justice and fairness. Another dispute among jurists is about acceptance or rejection of claim of duress by man and woman. Majority of jurists believe that if there is doubt to commit crime or attribute it to the defendant, punishment and Hadd should not be applied on him and if there is doubt to duress, it could be mentioned according to generality of the principle that punishment of this action is null and void.

The evidence for this group is statement of Abu Obaideh quoted from Imam Bagher: "a woman who has had illegal sexual relationship with a man was brought to Imam Ali. Woman said: I swear to God that this man has forced me with duress to do this and I had no authority and will and Imam Ali cancelled Hadd punishment for her as a result of this claim and acquitted her" (Borujerdi, 1999, vol.30, 656).

The mentioned statement refers to this issue that with the claim of duress on behalf of woman, judge faces doubt about punishment of woman and her punishment is cancelled through referring to principle of Ward of Hadd by suspicions. However, another group believes that when a man or woman claims that he-she is forced to do adultery with duress, such claim would be accepted and not only because of cancellation of Hadd as a result of doubt, but also because of existence of duress on adultery, hadd can't be proved until the time that its collapse is required and an action done by coercion is a sentence of absence and means that the coercer has taken no action (Khuyi, 2012, vol.2, 27-28).

Islamic Penal Code (approval of 1991) has accepted claim for duress on behalf of adulterer or adulteress, if there is no evidence against it. However, legislator has stated in note 1 of article 218 of the code (approval of 2013): "on crimes like Enmity against God and corruption on earth and crimes like sexual violence, duress, theft or deception are not just claim for hadd and the court is responsible for investigations."

As it is clear, legislator has considered criminalization of the article more strictly in note 1 of article 218 and has considered the basis on lack of coercion and has made the court responsible for investigation in this field; although it seems that it would not be allowed anymore if the judge has doubt on it. 
If the judge tends to investigate and explore the reality, this issue can be expressed certainly in crimes related to divine rights and privacy. Therefore, in divine Hadd and punishments that are based on declination and forgiving, immediately after emergence of doubt and claim of coercion (in case of probability of accuracy of this claim), the punishments should be null and void and rational principles like lack of coercion should not be applied for them.

\section{Duress in Sodomy}

The term "sodomy" applied to introduce physical behavior resulted from sexual desire between two men is one of the sexual deviations that has been existed since long time ago in many societies and has been always one of the antipathy and hatred issues for ordinary people that is punishable. The term "sodomy" (Livat) derived from the word (Lot) has been common among followers of Imam Lot and despite to abundant orders of Imam on prohibiting damages resulted from this hatred action, people used to take this negative and hatred action.

In verses 80 and 81 of Surah Al-A'araf, Holy God has mentioned in this field: "And [We had sent] Lot when he said to his people, "Do you commit such immorality as no one has preceded you with from among the worlds? ${ }^{80}$ Indeed, you approach men with desire, instead of women. Rather, you are a transgressing people. ${ }^{81 "}$

In terms of jurisprudence, if this action is done through entrance of penis to body of another man, it is named I'qab; although if the sensual pleasure is gained through contact of penis with thighs of another man, it is named Tafkhiz.

Islamic Penal Code (1991) has announced in article 108 through following opinion of majority of jurists about sodomy: " Sodomy (livat) is defined as sexual intercourse with a male, whether it takes place as penetration or tafkhiz [rubbing penis between thighs]."

However, in article 233 of Islamic Penal Code (2013), the Tafkhiz has been defined based on Livat as follows: "Livat is defined as penetration of a man's sex organ (penis), up to the point of circumcision, into another male person's anus."

Undoubtedly, one of the basic required conditions to authenticate criminal responsibility and considering doer of Livat as a criminal person in Islamic Penal Code is that Livat is done intentionally and in case of absence of this condition, Hadd can't be proved and punishment would be null and void. In sources of Imammi jurisprudence, death penalty is considered as Hadd of Livat and if the insertive and receptive parties have general conditions of responsibility like wisdom, maturity and authority, the hadd of death would be applied for them.

Islamic Penal Code (1991) in articles 110 and 111, has considered Hadd for Livat absolutely death penalty and in case of presence of wisdom, maturity and authority, the sentence should be enforced.

Article 110: "In the case of penetration, the hadd punishment for sodomy is the death penalty- the method for which is at the discretion of the judge."

Article 111: "Sodomy shall result in the death penalty provided that both the insertive and receptive parties are mature, sane and free."

Currently, in article 134 (2013), the legislator has announced: "The hadd punishment for livat shall be the death penalty for the insertive/active party if he has committed livat by using force, coercion, or in cases where he meets the conditions for ihsan; otherwise, he shall be sentenced to one hundred lashes. The hadd punishment for the receptive/passive party, in any case (whether or not he meets the conditions for ihsan) shall be the death penalty."

Clearly, the most important changes in this article in regard with Livat are that the condition to achieve death penalty of doer of livat is depended on 3 conditions and in case of lack of each condition, death penalty would be declined and the criminal person would be sentenced to a hundred lashes. It seems that the legislator has criminalized the article with easy taking view in field of penalty for livat; meaning that in Islamic Penal Code (1991), hadd for livat is death in case of penetration and existence of conditions; although in article 234 (2013), the legislator has considered death penalty for this crime in cases that the action is done under violence and duress; otherwise, if the doer has not used violence and coercion in this action and has taken it intentionally, the party should be sentenced to lashes.

According to investigations in Imami Jurisprudence, such theory has not been observed among jurists and great sheikhs of Islam and such criminalization looks unprecedented in Iranian Penal Codes about sodomy.

Another case, according to which legislator has criminalized it in field of voiding or declining penalties in crimes like adultery and sodomy can be the time that the defendant has repented. 
According to article 114 of Islamic Penal Code (2013), "In the case of offenses punishable by hadd, with the exception of qazf and moharebeh, if the accused repents any time before the commission of the offense is proved, and his/her regret and correction is certain in the eyes of the judge, the hadd punishment shall not be given. In addition, if the abovementioned offenses, except for qazf, are proved by confession, if the offender repents, even after the commission of the offense is proved, the court, through the Head of Judiciary, can apply for pardon of the offender by the Leader."

Note 2- In the cases of zina and livat, when the offense is committed by force or coercion or deception of the victim, if the offender repents and the [hadd] punishment is not given according to this article, s/he shall be sentenced to ta'zir imprisonment or flogging, or both, of the sixth degree.

According to article 114 and the mentioned note, in crimes resulting in hadd like adultery and sodomy by violence and coercion, role of repent of criminal person to change the penalty of hadd to Ta'azir has been considered and predicted in two modes as follows: first, in cases that the criminal has paid attention to his/her authority and intention before proving the crime and second, in cases that committed crime is proved through confession at the court.

It seems that elimination of punishment from the doer is a kind of forgiving in enforcement of Hudud as each of these actions should be punished with the hardest type of punishment in case of coercion; although drafters of Islamic Penal Code (2013) have considered repent of criminal party as returning to pure nature of human and have changed death penalty to Ta'azir penalties in crimes punished by hadd, especially in crimes of adultery and sodomy by violence and coercion.

\section{Duress in Crimes Punished by Qisas (Nemesis)}

Qisas is the infinitive from root "Ghess, Yaghess" and in juridical terms, it is a title for advocating crimes ranging from murder, assault and battery. The word lexically means following something and someone; it seems that the doer of Qisas follows the person who has committed the crime and takes similar action (Shahid Sani, ibid, 718).

Islamic Penal Code (2013) has revised lexical and idiomatical meanings of Qisasa in article 16: "Qisas is the main punishment for intentional bodily crimes against life, limbs, and abilities which shall be applied in accordance with Book One of this law."

\section{Duress in Murder}

Article 381 of the said law has sufficed to idiomatic meaning of Qisas: "punishment for murder is Qisas in case of demand of owner of blood and existence of other conditions codified in law; otherwise, other punishments would be applied like Diya (blood money) and Ta'azir."

According to this article, the punishment would be death penalty, when the innocence is eliminated intentionally and according to consensus of majority of Imami Jurists, in case of existence of coercion to murder, distortion of authority and will can't affect elimination of innocence and can't lead to declination of punishment and exemption of the unwilling party from tolerating it.

In fact, the punishment for unwilling party who has considered rest of his/her life depending on getting life of another one and has killed him/her intentionally is allowed and no objection is accepted (Mohaqeq damad, 2012, vol.4, 116).

According to this opinion, the hadith of elimination would not be generalized to this issue, since the hadith is presented for affairs to forgive people and if declining the sentence anywhere intensifies conditions and, the hadith of elimination has no impact and Qisas should be enforced.

On the contrary, a group has considered the punishment of Diya (blood money) in this case (Khuyi, 2012, 29).

Islamic Penal Code (2013) has also followed majority of Imami jurists: " duress in murder is not the permission for murder and it should be punished by Qisas and the coercer would be sentenced to life imprisonment."

It seems that in terms of observance of principles of fairness and justice, the coercer should not be responsible because of commitment of murder of a willing man who can kill another person. Here, the problem is not that whether killing someone to be safe against death is true or not, but also the problem is that if someone takes such action, he/she should not be punished necessarily as a willing murderer.

\section{Duress in Crime on Body Organs}

According to article 387: "crime on body organ refers to any kind of damage less than murder like Mutilation, injury and damaging interests" 
As it was mentioned, a person can be punished in case of having absolute will and intention; although any person who has had coerced to commit crime on organ of another person irrevocably, Qisas permission can't be issued for it.

Majority of jurists, despite to duress in murder, have accepted duress in crime on body organ and have considered coercer responsible for this action. In cases of Qisas, the coercer has been punished by Qisas and in case of paying Diya, the coercer is responsible to pay it (Shahid Sani, ibid, 722-723).

Against these opinions, a group believes that in this case, the perpetrator should pay the blood money, since coercer has been a reason for crime on organ and perpetrator has committed the crime and as he has no will and intention, the blood money should be paid, since blood of no Muslim should be wasted (Khuyi, ibid, 35).

In Islamic Penal Code (1991), no text is presented on crime on organs and it seemed previously that the legislator had assigned regulations of duress in crime on organ to general regulation of coercion in article 54 (1991) through his silence; although through investigation of the article, it could be found that inserted crime sin this article are associated with Ta'zir and deterrent crimes. Such gap and lack of article about duress on crime on organ has made legislator of Islamic Penal Code (2013) and has criminalized the article in article 377 as follows: " duress in crime on organ can lead to Qisas of the coercer". However, an ambiguity about coercion in murder and duress in crime on organ is that the legislator has expressed the desired duress in both of them absolutely and without specifying limitation.

However, article 151 (2013) on Ta'zir crimes has mentioned that anyone, who, as a result of an unbearable duress, commits a conduct that is considered by law as an offense, shall not be punished. In the cases of offenses punishable by ta'zir, the coercer shall be sentenced to the punishment provided for the offender of the offense. In the cases of offenses punishable by hadd and qisas, the relevant provisions shall apply. About conditions of the coercer and coerced party on crimes punished by Qisas, the issue has been assigned to book 3 (2013); although in same regulations, duress has been expressed absolutely and no separation is considered between bearable and unbearable coercion.

If the desired duress of article 375 (2013) is considered as bearable duress that may result in a few damages for the coerced, the said sentence based on Qisas of coercer seems correct. However, if the desired duress of legislator is considered as unbearable duress and the will and intention of coercer is destroyed totally and the mental element is distorted, intentionality of murder and considering Qisas for it is against general principles dominated on Criminal Code and principle of necessity of actual existence of mental element in realization of criminal action and the type of punishment should be revised.

About article 377 (2013), it seems that if the desired duress is considered as unbearable duress, the sentence of legislator is against principles of justice and if so, acceptance of punishment on coercer is fair; although if the mentioned duress is unbearable, accepting the punishment of coercer is fair. As a result, legislator should specify type of duress to meet the ambiguities.

\section{Crime on the Coerced Party}

Another crime that may be committed by the coercer is to threaten another person to take an abominated action and this can result in committing crime on the coerced party. About type of punishment of the coercer in field of crime on the coerced party, there are many disputes among great jurists. In this case, the coercer is responsible to pay blood money and not Qisas (Khomeini, ibid, 281). However, some jurists believe that neither Qisas, nor blood money is allowed on the coercer (Khuyi, ibid, 36).

As a result, in Imami jurisprudence, a group considers blood money in any case for coercer and another group considers absolutely no punishment for coercer, whether intentional or quasi-intentional.

Through criminalization of the crime, the legislator has created a new approach in coercion of crime on the coercer. Article 379 of Islamic Penal Code (2013) mentions: "if a person coerces another one to do something that results in crime on coercer, the crime is intentional and the coercer would be punished by Qisas. If the coercer has had no intention to commit crime on him/her and has not also considered this issue that the duress can lead to crime on him/her, the crime is considered as a quasi-intentional crime and the coercer should pay blood money."

According to this article, it seems that legal nature of coercion in crime on coerced party has been divided to two intentional and quasi-intentional groups and in case of intentional crime, the punishment would be Qisas and in case of quasi-intentional crime, the punishment on coercer would be paying blood money.

One of the shortcomings of this article is lack of reference to legal nature of crime on coercer as a clear mistake, 
since according to article 289 that classifies crimes to three groups of intentional, quasi-intentional and mere mistake, and the crime may be occurred as mere mistake. In this case, the mistake is in inattention to crime on coercer in case of occurrence as mere mistake; for example, the coercer is an immature or insane person that his/her action is considered as mere mistake in terms of law. In this case, the punishment would be Diya (blood money).

\section{Conclusion}

According to the studies, coercion in Hudud can cause exemption from punishment because of negligence (easy taking) by the legislator in field of enforcement of Hudud; although Islamic Penal Code has not considered Zina (adultery) as a criminalized action despite to acceptance of duress by the adulterer and adulteress in Imami jurisprudence and Islamic Penal Code (1991). Moreover, in field of claim for duress, this issue is depended on exact investigations in the court; although in crimes related to divine penalties related to privacy of people, no investigation should be done. In case of Livat (sodomy), the legislator considers death penalty for this crime in cases that punishment of the action is taken with coercion and violence; otherwise, the penalty would be 100 lashes. However in Imami jurisprudence, if the coercer has taken this action whether with duress and violence or with consent of the passive partner, the hadd for murder would be enforced for them. In Islamic Penal Code (1991), through following Imami jurists, if the doer or passive partner has taken this action intentionally, the punishment for murder would be enforced for that. As a result, a kind of forgiveness can be observed in enforcement of Hudud in Islamic Penal Code (2013) on Livat (sodomy).

On duress on murder, despite to opponent opinions in Imami jurisprudence and accepting it by this group, it has not been accepted in view of majority of jurists and the former and new Islamic Penal Codes have accepted opinion of majority of jurists in this regard; meaning existence of duress in murder. However, the viewpoint has some problems, since if the desired coercion in article is considered as unbearable duress; the coercer is forced to do something out of his/her ability. In case of duress on crime on organ, according to majority of jurists, when the punishment is Qisas, coercer should be punished and if the punishment is paying blood money, the coercer should pay the blood money.

Contrary to criminalization of former Code, the New Islamic Penal Code has accepted opinion of majority of Imami Jurists and if a person is forced to commit crime on body organ of another person, the passive partner would be acquitted and the coercer would be responsible for the action and should be punished.

\section{References}

Al-Jabei al-Ameli, Z. B. A. (2012). to explain Damascene shines, trans. Asadullah Lotfi, Tehran Majd publication.

Amid, H. (1984). AMID Dictionary (Vol. I). Tehran, Amir Kabir publication.

Borujerdi, S. H. (1999). Sources of Shiite jurisprudence, translated by Ahmad Ismail origin et al., Volume thirtieth, Qom, Farhange Sabz Press.

Isfahani, A. H. (1973). Vasilat An-Nejat (Vol. II). Qom, Dar Al-Olum Press.

Karim Quran.

Khuyi, A. (2012). Takmale al-Minhaj, translated by Alireza Saeed, Volume II, Tehran, Khorsandi Press.

Mohaqeq Damad, S. M. (2012). rules of jurisprudence (Criminal Chapter) (Vol. IV, 24th ed.). Tehran, Islamic science publishing

Mousavi Khomeini, R. (1990). Tahrir ul-Vassileh, translated by Ali Eslami, Volume IV, Islamic Propagation Office affiliated to the Society of Teachers of Qom Seminary.

\section{Copyrights}

Copyright for this article is retained by the author(s), with first publication rights granted to the journal.

This is an open-access article distributed under the terms and conditions of the Creative Commons Attribution license (http://creativecommons.org/licenses/by/3.0/). 